\title{
Direito cooperativo como lacuna na análise antitruste - o caso das cooperativas de saúde no Brasil
}

Derecho Cooperativo como vacío en el análisis antitrust - el caso de las cooperativas de salud en Brasil

\author{
Cooperative Law as a vacuum in antitrust analysis - the case \\ of health cooperatives in Brazil
}

\section{Ronaldo Gaudio* Enzo Baiocchi ${ }^{\star \star}$}

Recibido: 1 de agosto de 2018 Aceptado: 16 de octubre de 2018 Publicado: 5 de abril de 2019

Cómo citar este artículo: Gaudio, R y Baicocchi, E. (2019). Direito cooperativo como lacuna na análise antitruste - o caso das cooperativas de saúde no Brasil. Cooperativismo \& Desarrollo, 27(1), 1-30. DOI: https://doi.org/10.16925/2382-4220.2019.01.12

Artículo de investigación. https://doi.org/10.16925/2382-4220.2019.01.12

* Especialista en Derecho Empresarial. Afiliado a Universidade do Estado do Rio de Janeiro, Brasil.

Correo electrónico: HYPERLINK “mailto:gaudio@gn.adv.br" gaudio@gn.adv.br

** Profesor adjunto de Derecho Comercial, Facultad de Derecho Universidade do Estado do Rio de Janeiro, Brasil.

Correo electrónico: HYPERLINK “mailto:enzo.baiocchi@direito.ufrj.br” enzo.baiocchi@direito.ufrj.br 


\section{Resumo}

O artigo pretende explicitar algumas das possíveis contribuições do Direito Cooperativo para uma análise integrada dos possíveis casos de conflito em matéria antitruste envolvendo cooperativas. Tem-se como hipótese que, se por um lado existe pouco conhecimento e divulgação sobre o cooperativismo no setor acadêmico não especializado, não há, por outro, qualquer incompatibilidade apriorística entre os objetivos da conduta de cooperação cooperativista e os objetivos do Direito Concorrencial. Ao contrário, a identificação de parâmetros estruturais do Direito Cooperativo e sua recepção no ordenamento jurídico por meio de parâmetros constitucionais destinados ao exercício da atividade cooperativista permitem estabelecer o diálogo das fontes com base na ideia de desenvolvimento, que não se limita ao significado de crescimento econômico. A título de demonstração, critica-se a jurisprudência consolidada sobre a possível ilicitude concorrencial consistente em algumas práticas no âmbito das cooperativas de saúde. Com base na doutrina e na legislação, propõe-se, a título de demonstração final, uma aplicação adaptada das válvulas de escape da lei que estrutura o Sistema Brasileiro de Defesa da Concorrência (Lei n 12.529/2011).

Palavras-chave: Direito da Concorrência, Direito Cooperativo, cooperação cooperativista, cooperativas de saúde, regulação, desenvolvimento.

\section{Resumen}

El artículo busca explicitar algunos de los probables aportes del Derecho Cooperativo a un análisis integrado de los posibles casos de conflicto en materia antitrust que involucran cooperativas. Se plantea como hipótesis que, si por una parte existe poco conocimiento y divulgación acerca del cooperativismo en el sector académico no especializado, no hay, por otra, cualquier incompatibilidad apriorística entre los objetivos de la conducta de cooperación cooperativista y los objetivos del Derecho de Competencia. En cambio, la identificación de parámetros estructurales del Derecho Cooperativo y su recepción en el ordenamiento jurídico por medio de parámetros constitucionales destinados al ejercicio de la actividad cooperativista permiten establecer el diálogo de las fuentes con base en la idea de desarrollo, que no se limita al significado de crecimiento económico. Como demonstración, se critica la jurisprudencia consolidada sobre la posible ilicitud de competencia consistente en algunas prácticas en el ámbito de las cooperativas de salud. Basados en la doctrina y la legislación, se plantea una aplicación adaptada de las "válvulas de escape" de la ley que estructura el Sistema Brasileño de Defensa de la Competencia (Ley 12.529/2011).

Palabras clave: Derecho de Competencia, Derecho Cooperativo, cooperación cooperativista, cooperativas de salud, regulación, desarrollo.

\section{Summary}

The article seeks to explain some of the probable contributions of Cooperative Law to an integrated analysis of possible antitrust cases involving cooperatives. It is hypothesized that, if on the one hand there is little knowledge and disclosure about cooperativism in the non-specialized academic sector, there is no a priori incompatibility between the objectives of cooperative cooperation behavior and the objectives of Competition Law. . On the other hand, the identification of structural parameters of the Cooperative Law and its reception in the legal system by means of constitutional parameters destined to the exercise of the cooperative activity allow to establish the dialogue of the sources based on the idea of development, which is not limited to the meaning of economic growth. As a demonstration, the consolidated jurisprudence on the possible illegality of competition consisting of some practices in the field of health cooperatives is criticized. Based on the doctrine and legislation, an adapted application of the "escape valves" of the law that structures the Brazilian System of Defense of Competition (Law 12.529 / 2011) is proposed.

Key words: Competition Law, Cooperative Law, cooperative cooperation, health cooperatives, regulation, development. 


\section{Introdução}

O cooperativismo tem suscitado importantes debates no campo da defesa da livre concorrência, com maior incidência sobre algumas práticas de cooperativas que operam no mercado de saúde. No Brasil, há dois tipos de litígios com maior incidência nesse mercado, produzindo tanto jurisprudência administrativa por parte da autoridade regulatória antitruste (CADE - Conselho Administrativo de Defesa Econômica) quanto judicial (especialmente, pelo STJ - Superior Tribunal de Justiça). O primeiro caso, diz respeito à suposta conduta de cartel praticada por profissionais da área da saúde ( no caso específico, médicos) por meio de cooperativas de trabalho especializado, sobretudo as de serviços de anestesiologia ${ }^{12}$. O segundo caso, está relacionado à inclusão de cláusulas de exclusividade nos contratos celebrados entre cooperativas de planos de saúde e seus respectivos sócios (médicos e dentistas), que operam planos e seguros privados de assistência médica à saúde, no sistema brasileiro de saúde suplementar, regulado pela ANS - Agência Nacional de Saúde Suplementar ${ }^{3}$.

Nesse contexto, o presente artigo tem como objetivo demonstrar que, salvo casos específicos de violação da lei antitruste (no Brasil, Lei n 12.529, de 30.11.2011), o comportamento de cooperação econômica em geral, e o das cooperativas médicas em particular, está de acordo com os princípios do cooperativismo e da livre concorrência. Ademais, este estudo busca evidenciar que o desenvolvimento nacional, enquanto objetivo fundamental do Estado (artigo $3^{\circ}$, inciso II, da Constituição da

1 Processo Administrativo nº 08012.007042/2001-33, de 26 de abril de 2006. Sendo interessados o Comitê de Integração de Entidades Fechadas de Assistência à Saúde - CIEFAS, Luiz Fernando Mouta Moreira, Coopanest/BA - Cooperativa dos Médicos Anestesiologistas da Bahia, Estefânia Ferreira de Souza Viveiros, Ursula Ribeiro de Figueiredo Teixeira, Dalvio Jorge, José Carlos Jorge, José Curvello Filho, Regina Amarante, Allyne Borges de Faria, Marcelo Cintra Zarif, Liege Ayres de Vasconcelos, Caio Druso de Castro Penalva Vita, luri Vasconcelos Barros de Brito, Betânia Rodrigues, Raquel Carneiro Santos Pedreira Franco, Mario Victor Ventura de Oliveira Santos. Disponível em <https://sei.cade.gov.br/sei/modulos/pesquisa/md_pesq_processo_exibir. php?0c62g277GvPsZDAxA01tMiVcL9FcFMR5UuJ6rLqPEJuTUu08mg6wxLt0JzWxCor9mNcMYP8UAjTVP9dxRfPBcd9UGKvnfU2DUJMijam0u9uWHIYXVi5oeZz_YMZQaE1A>. Acesso em: 10/07/2018.

2 Apelação Cível no 0082460-27.2009.8.19.0001. TJRJ. Rel. Des. Celso Luiz de Matos Peres. Décima Câmara Cível. Julg. 30/11/2011. Apelantes: Cooperativa dos Cirurgiões Cardiovasculares do Estado do Rio de Janeiro - CARDIOCOOP RJ e Associação de Medicina de Grupo do Estado do Rio de Janeiro. Apelados: Os mesmos. Disponível em: <http://www1. tjrj.jus.br/gedcacheweb/default.aspx?UZIP=1\&GEDID=00032D22322F4F85D4DDADA621A1A6D11FCE3FC40317312A\&USER=> . Acesso em: 10/07/2018.

3 EREsp 191.080/SP. Rel. Min. Hamilton Carvalhido. Corte Especial. Julg. 16/12/2009. Embargante: Agência Nacional de Saúde e Argemtro Dolce e Outros. Disponível em: <https://ww2.stj.jus.br/ processo/revista/documento/mediado/?componente=ATC\&sequencial=6500605\&num_registro $=200900989862 \&$ data $=20100408 \&$ tipo $=51 \&$ formato $=P D F>$. Acesso em 10/07/2018. 
República Federativa do Brasil de 1988) e princípio constitucional impositivo dotado de caráter constitucionalmente conformador (conforme lições de GRAU, 2015, p. 213), constitui a instância na qual se estabelece o diálogo integrador entre cooperativismo e livre concorrência.

Contudo, ressaltamos que o objetivo desta pesquisa não é aprofundar a análise desses tipos de litígio, mas, sim, demonstrar a necessidade de integrá-la pelos aportes próprios de Direito Cooperativo. Para tanto, elegemos o segundo caso (cláusulas de exclusividade) para um aprofundamento teórico e prático.

Concorrência (competição) e cooperação são comportamentos de agentes econômicos que, embora antagônicos, podem, eventualmente, caracterizar uma conduta anticoncorrencial. Nas cooperativas, a cooperação econômica possui uma tipicidade própria que é estruturante de seu regime jurídico, tendendo a originar tanto acordos verticais quanto horizontais entre pessoas naturais e jurídicas, preponderantemente ligadas por uma relação societária.

A partir dessa perspectiva, procura-serealçarcomotais elementos estruturantes e sua recepção pela Constituição Federal estabelecem esse regime jurídico próprio e um conjunto de vetores para uma adequada interpretação dessas atividades no plano do antitruste. Como consequência, será possível evidenciar que, ao invés da configuração de ilícitos antitruste per se, o cooperativismo está vocacionado de forma singular à ampliação da concorrência e do próprio desenvolvimento - onde especialmente se opera o diálogo constitucional entre Direito da Concorrência e Direito Cooperativo.

A vocação do cooperativismo para o desenvolvimento o fez, inclusive, ser incluído como uma das principais estratégias da Organização das Nações Unidas para concretização dos Objetivos de Desenvolvimento Sustentável (ODS) ${ }^{4}$. Tratase de uma das várias evidências de que o Direito Cooperativo, que diz respeito ao regular regime jurídico das cooperativas, dialoga com o Direito da Concorrência na tutela do interesse de desenvolvimento. Esse diálogo pode se estabelecer de forma pragmática, inclusive, como importante fundamento para a aplicação das válvulas de escape previstas no Sistema Brasileiro de defesa da Concorrência - instrumentos de flexibilização das normas antitruste bom base na análise do efeito das condutas 5 .

4 Os Objetivos de Desenvolvimento Sustentável constam do documento Agenda 2030, publicada pela ONU: Disponível em <https://nacoesunidas.org/wp-content/uploads/2015/10/agenda2030-pt-br.pdf>, Acesso em 10/05/2018.

5 Como exemplo de julgamento precedente, o processo administrativo $n^{\circ}$ 08012.003048/2003-01. Representados: Conselho Regional de Medicina do Estado do Ceará,; Sindicato dos Médicos do Estado do Ceará;Associação Médica Cearense. Julgamento em 29 de janeiro de 2015. 
Assim, os benefícios específicos das cooperativas devem ser considerados por ocasião de para promoção de um eventual aperfeiçoamento da jurisprudência ou até mesmo através da correção desta através da regulação, pois se revela que esse tipo de sociedade constitui importante instrumento de políticas de desenvolvimento diferenciado, superior e socioeconomicamente sustentável.

\section{Os desafios do Direito Cooperativo.}

Há um tempo considerável, a doutrina nacional vem observando que a atenção da pesquisa acadêmica e o tratamento do próprio Estado ao cooperativismo não têm sido congruentes com sua importância econômica e científica. E isso, desde a necessidade do incremento do número de pesquisadores nos diferentes campos de conhecimento intrínsecos às cooperativas (JOHANNEN, 1973, p. 11-12) até contundentes críticas ao comportamento estatal para o setor (BULGARELLI, p. 8), não faltando evidências da precária realidade do cooperativismo e das disciplinas a ele relacionadas. Ao confessar a existência de certo preconceito em face das cooperativas, Paula Forgioni (2014, p. 57-72) arrola alguns questionamentos sobre essas sociedades em razão do simples desconhecimento de suas peculiaridades estruturais e até a falta de coerência de argumentos que costumam ser manejados em desfavor das cooperativas. Nesse sentido, Diva Benevides Pinho (1962, p. 69) registra que desde os primórdios do cooperativismo moderno ${ }^{6}$ as cooperativas são confrontadas pela racionalidade econômica hegemônica por parte do próprio Estado: "(...) o procurador geral de Lyon, ao tomar conhecimento da cooperativa de consumo aí fundada em 1835, comunica o fato ao prefeito escrevendo que 'a polícia descobriu desusado gênero de comércio que parece ser a máscara de uma associação ilícita'". Tivemos a oportunidade de confirmar esse dilema, na atualidade da prática cooperativista, a partir de uma análise inicial sobre a lei especial das cooperativas de trabalho brasileira (GAUDIO, 2014, p. 88-107), da crítica sociológica de Boaventura de Sousa Santos sobre o padrão de racionalidade que rechaça a experiência cooperativista

Disponível em: <https://sei.cade.gov.br/sei/modulos/pesquisa/md_pesq_processo_exibir.php?2pXoYgv29q86Rn-fAe4ZUaXIR3v7-gVxEWL1 JeB-RtUgqOwvr6ZlwydlOIhRNSr2Q22IByVKByYDYwsa13_Jxgo7gV6DwMSVWJ26I-r8kcT5FFAo2XTb_X8IXmwbDjgR>. Acesso em 11/07/2018.

6 Apesar da evidência de que existiam entidades associativas reconhecidas materialmente como cooperativas antes de 1844 (BALAY, 1965, p. 62), a partir deste marco temporal se afırma o nascimento do cooperativismo moderno, representado pela constituição da Rochdale Society of Equitable Pioneers, no condado de Lancashire, na Inglaterra, conhecida como cooperativa de Rochdale, cujo êxito na construção de um programa de princípios e regras práticas até hoje influenciam a organização e o funcionamento de cooperativas em todo mundo (MLADENATZ, 2003, p. 77). 
(GAUDIO; HELFER, 2014) e o papel da universidade contra o desperdício dessa experiência em favor do desenvolvimento (GAUDIO; SOARES, 2017, p. 197-213).

Tudo isso ocorre apesar da doutrina reconhecer a existência do Direito Cooperativo (BECHO, 2012) como ramo autônomo do Direito (ANDRIGHI, 2005) há décadas (BULGARELLI, 1967, p. 117-159) e do reconhecimento do papel diferenciado que as cooperativas cumprem em prol do desenvolvimento socioeconômico (BENECKE, 1980, p. 77-78; 109-135; NAMORADO, 2000, p. 12).

A rigor, esse desafio parece permear problemas culturais em diferentes países, sendo a superação do desconhecimento uma ação estratégica para que as cooperativas possam cumprir seu papel para geração de desenvolvimento socioeconômico (DELGADO, 2017, p. 20-22). Acerca desse problema, Rui Namorado (2000, p. 24-26; 76-81) considera que, apesar de representar uma prática cotidiana, o cooperativismo, enquanto fenômeno social, possui uma profundidade histórica escassa, tornando-se subalterno de outros modelos socioeconômicos. Em razão disso, seu exercício - segundo este autor - não está permeado nas "camadas estruturantes do sistema jurídico", fazendo com que haja uma incidência de intervenções legislativas inadequadas que o descaracterizam, e essa subalternidade se relaciona com o fato de o método cooperativista representar um desafio à lógica econômica hegemônica. Algo análogo se passaria inclusive naqueles países cuja economia não se paute pelo livre mercado, como em Cuba (HARNECKER, 2012).

Por seu turno, as universidades, sobretudo as públicas, têm um importante papel a desempenhar como elemento estratégico difusor de conhecimento para a superação dos entraves associados ao desconhecimento do cooperativismo e dos desafios impostos pela racionalidade econômica hegemônica, em favor do desenvolvimento da sociedade (MUCIÑO, 2008, P. 87-127). Apesar de alguns avanços ao longo do tempo, tanto a investigação quanto a docência ainda são incipientes (CRACOGNA, 2000, p. 59-64).

De forma a contextualizar esses desafios particulares das cooperativas, é importante considerar que a resposta estatal ao desvio no meio capitalista é sempre no sentido de aperfeiçoar o regime jurídico das empresas, visando renovar, manter e legitimar o próprio sistema capitalista (GRAU, 2015, p. 43-44). Contudo, tal assertiva não se processa com a mesma agilidade ou até mesmo com idêntico propósito em relação ao cooperativismo. É justamente esse o desafio sobre o qual se debruçam ao longo do tempo doutrinadores de tradição cooperativista (LASSERRE, 1972, p. 115-116; DELGADO, 2017, P. 141-143).

A falta de conhecimento ou, até mesmo, de interesse sobre a lógica peculiar do cooperativismo costuma ser reconhecida como fator desafiador para uma completa 
e adequada interpretação da atuação das cooperativas na análise antitruste (FORGINI, 2014, p. 57-72). Suas práticas comumente são reputadas como atos de concentração ilícita per se (OLIVEIRA, 2014, p. 86).

Entretanto, é importante notar que o cenário de desconhecimento é sempre muito bem aproveitado pelos empresários que concorrem com as cooperativas. Geroges Lasserre (1972, p. 49-52) já afırmava que a expansão da atividade cooperativista sempre enfrenta a resistência e a hostilidade de empresários que, ao serem obrigadas a baixar seus preços para concorrerem com as cooperativas, utilizam todos os expedientes para alijá-las dos mercados. Dentre as estratégias historicamente registradas pelo autor há, desde fortes campanhas difamatórias contra o modelo cooperativista até, e especialmente, a cooptação do Estado para restringir a liberdade de funcionamento e de organização de consumidores e trabalhadores em cooperativas.

\section{Cooperativismo e concorrência: o caso das cooperativas de saúde.}

De acordo com levantamento feito pela doutrina, até 2007 , quase $75 \%$ dos processos administrativos sancionadores que tramitaram no CADE envolviam cooperativas médicas, seja tratando especificamente das cláusulas de exclusividade? ${ }^{7}$ sejam versando sobre outros mecanismos de exercício de poder em mercado por cooperativas de saúde (CUEVA, 2008, p. 73). Em razão dessa elevada incidência de litígios, esses casos são comumente citados para analisar os possíveis efeitos concorrenciais das cooperativas de saúde e também como forma de demonstrar as possíveis contribuições do Direito Cooperativo em matéria concorrencial.

\subsection{Unimilitância: fidelidade societária entre colusão e cooperação.}

Entende-se pelo termo "unimilitância" a prática de certas cooperativas operadoras de planos de saúde de exigir dos seus sócios (médicos e dentistas) uma fidelidade societária consistente no dever de não participar da rede de atendimento de operadoras concorrentes, isto é, um dever de não concorrer com a cooperativa, da qual fazem parte na condição de sócios. Tal obrigação era contraída explicitamente através de cláusulas estatutárias aprovadas em assembleia geral, que foram consideradas como cláusulas de exclusividade. Contudo, ressalta-se que essas obrigações não se

7 O fenômeno será mais bem esclarecido no subcapítulo seguinte. 
estendem aos clientes particulares dos médicos cooperados - a negociação direta e contratação desses profissionais por seus pacientes (consulta privada). A restrição é no sentido de que o cooperado não trabalhe para outra sociedade concorrente da cooperativa, ou seja, outras operadoras de planos médicos e odontológicos. Assim sendo, não se trata de uma exclusividade absoluta, do ponto de vista laboral, mas de uma restrição relativa às entidades que atuam com o mesmo objeto social das cooperativas.

Os argumentos em favor da "unimilitância", em síntese, são articulados com base nesse dever de fidelidade (de não competir) do sócio-cooperado, em não operar com concorrentes da própria sociedade cooperativa. Salienta-se que o art. 29, $\S 4^{\circ}$ da Lei n 5 5.764/1971 (Lei Geral de Cooperativas - LGC) já veda o ingresso de agentes econômicos concorrentes das cooperativas em seu quadro social. Vale dizer que o dever de lealdade dos sócios não é exclusivo das sociedades cooperativas e que, "embora difuso, estará tanto mais presente quanto maior for o grau de identificação do sócio com a vida social" (BORBA, 2015, p. 42-43). Portanto, trata-se de uma obrigação relacionada com a própria affectio societatis.

É relevante considerar que, em regra, as cláusulas de exclusividade não são vedadas pelo Direito (BAGNOLI; BASTOS, NAVAS, 2014, p. 33). Na jurisprudência favorável à unimilitância, que - cabe ressaltar - não constitui hoje o entendimento majoritário, era possível identificar o reconhecimento de que as cláusulas de exclusividade se apresentam de formas distintas no ordenamento jurídico e que, quanto às cooperativas operadoras de planos de saúde, uma interpretação adequada da legislação antitruste não poderia conduzir a sua configuração como um ilícito concorrencial se fossem razoáveis, isto é, se o pacto de exclusividade tivesse intenção ou efeito de ampliar a concorrência ou favorecer o desenvolvimento econômico ${ }^{8}$.

Além disso, invoca-se a existência do regime próprio diferenciado das cooperativas, reconhecido na Constituição Federal ${ }^{9}$. Alega-se que a existência da diretriz constitucional de apoio e estímulo ao cooperativismo (art. 174, $\S 2^{\circ}$, da CF/1988) seria um fator de bloqueio de iniciativas estatais de reprimir a unimilitância,

8 Recurso Especial n 261.155-SP, Relator: Rui Rosado de Aguiar, julgado em 10/03/2004. Recorrente Marialda meyer de Castro Araújo. Recorrido: Unimed Rio Claro Cooperativa de Trabalho Médico. Disponível em: <https://ww2.stj.jus.br/processo/revista/documento/mediado/?componente=ATC\&sequencial $=796987 \&$ num_registro $=200000532983 \&$ data $=20040503 \&$ tipo $=68 \&$ formato $=P D F>$. Acesso em: 18/08/2018.

9 Acolhendo também essa linha, por exemplo, veja-se Recurso Especial n 126.391-SP, Relator: Min. Waldemar Zveiter, $3^{a}$ turma, 3 de agosto de 1999. Recorrente: Unimed Rio Claro Cooperativa De Trabalho Médico. Recorrido: Ibrahim Georges Buttros Neto e Outros. Disponível em: <https:// ww2.stj.jus.br/processo/ita/documento/mediado/?num_registro=199700233367\&dt_publicacao=27-09-1999\&cod_tipo_documento=3\&formato=PDF $>$. Acesso em: 18/08/2018. 
na medida em que tenderiam a desestimular a atividade cooperativista. A livre iniciativa, ratificada também quanto ao exercício da atividade cooperativista por meio do art. 5, inc. XVII, da CF/1988, consistindo um direito fundamental dos sócios das cooperativas, impediria uma interpretação constitucional que limitasse a liberdade destes de estabelecer democraticamente as cláusulas de exclusividade (CONTO, 2012, p. 69).

Assim sendo, conquanto seja plenamente coerente e lícito, a priori, o estabelecimento dessa vedação de operação entre sócio cooperado e concorrentes da cooperativa, é importante sondar se haveria no, Direito Cooperativo, alguma particularidade que justifique a restrição generalizada do dever de fidelidade por iniciativa estatal, pois foi exatamente isso que aconteceu.

Em 2008, a Agência Nacional de Saúde Suplementar editou a Resolução Normativa $n^{\circ}$ 175, que estabeleceu o entendimento contrário à exigência de unimilitância nos estatutos das sociedades cooperativas. Com base nessa norma, a autoridade regulatória passou a proibir a toda e qualquer cooperativa operadora de planos médicos ou odontológicos, independentemente do mercado geograficamente relevante, de alterar seus estatutos sociais de modo a impedir qualquer exigência de exclusividade de seus cooperados, ou seja, a Resolução Normativa n 175/2008 vedou a cláusula de exclusividade (e, com isso, a unimilitância) nas cooperativas de planos de saúde. A inserção de uma norma proibitiva no texto dos estatutos sociais foi imposta, em termos ditados pela $\mathrm{ANS}^{10}$, como condição para manutenção e concessão de autorização de funcionamento das sociedades cooperativas. Esse ato de regulação normativa estaria ancorado na própria Lei n 9.656/1998 (que estabelece os aspectos gerais sobre os planos e seguros privados de assistência à saúde), a partir de uma alteração do inciso III do artigo 18, operada pela Medida Provisória $n^{\circ} 2.177-44 / 2001$.

A partir de 2010, dois anos após a Resolução Normativa da ANS citada acima, a jurisprudência do Superior Tribunal de Justiça se consolidou no sentido de reconhecer a ilicitude concorrencial de tais cláusulas de exclusividade. Reconheceu-se uma potencialidade lesiva genérica de que essa prática seria um ato lesivo à concorrência per se, apto a criar barreiras de entrada ou à permanência de concorrentes no mercado de saúde suplementar, pois as operadoras de planos de saúde não cooperativas

10 Resolução Normativa n 175/2008, art. 1 ${ }^{\circ}$ : "Em se tratando de pessoa jurídica organizada sob a forma de sociedade cooperativa, seu ato constitutivo deverá conter a seguinte cláusula: Nenhum dispositivo deste Estatuto deverá ser interpretado no sentido de impedir os profissionais cooperados de se credenciarem ou referenciarem a outras operadoras de planos de saúde ou seguradoras especializadas em saúde, que atuam regularmente no mercado de saúde suplementar, bem como deverá ser considerado nulo de pleno direito qualquer dispositivo estatutário que possua cláusula de exclusividade ou de restrição à atividade profissional." 
passariam a ter dificuldade de conveniar profissionais para cumprirem seus contratos de assistência à saúde. A prática incorreria em condutas ilícitas (então previstas na Lei $\left.n^{\circ} 8.884 / 1994\right)^{11}$, presumindo-se que a exigência de fidelidade societária consistiria, per se, numa exigência de exclusividade ilícita sob a perspectiva da defesa da concorrência, pois estaria fadada a produzir a dominação de mercados, a eliminação de concorrentes e aumentos arbitrários dos preços das cooperativas. ${ }^{12}$ Cabe lembrar que esse cenário se consolidou antes da vigência da nova Lei Antitruste (Lei n 12.529, de 30.11.2011).

No tocante à unimilitância, após os processos judiciais e administrativos que envolveram a matéria, parece-nos que há uma flagrante tutela equivocada por parte do Estado Regulador, por meio da Resolução Normativa da ANS nº 175/2008.E isso, porque concebe a prática de unimilitância como um ilícito concorrencial per se, restringindo-a de forma incondicionada, independentemente da configuração de poder de mercado ou de seu abuso por parte de qualquer cooperativa.

Apesar do dever de não concorrência com a própria sociedade (dever de lealdade) constituir um corolário geral da condição de sócio (BORBA, 2015, p. 42-43) e os estatutos sociais constituírem o principal elemento da autonomia privada no Direito Societário (TELLECHEA, 2016, p. 346), a norma regulatória, prevista no art. $1^{\circ}$ da Resolução Normativa ANS n 175/2008, impõe essa cláusula societária obrigatória às sociedades cooperativas, independentemente de estar configurado, in concreto, uma conduta anticoncorrencial, prevista noartigo 36, caput e seus incisos, da Lei $\mathrm{n}^{\circ}$ $12.529 / 2011$.

\subsection{O problema com as cooperativas de especialidades médicas}

Considerando o escopo do artigo em evidenciar a possibilidade de integração entre as normas antitrustes e as do cooperativismo, apenas indicaremos a existência da outra polêmica em torno de litígios envolvendo cooperativas médicas em matéria de defesa da concorrência.

11 A lei foi revogada e substituída pela Lei $n^{\circ} 12.529 / 2011$, que estrutura o Sistema Brasileiro de Defesa da Concorrência. Sobre a posição dominante, vide, e.g., Recurso Especial n 1.172-603RS, Relator: Min. Humberto Martins, $2^{\text {a } T u r m a, ~} 4$ de março de 2010. Disponível em <www.stj.jus. $\mathrm{br} /$ docs_internet/informativos/RTF/Inf0425.rtf >. Acesso em 17/05/2018.

12 Nesse sentido, v. REsp n 768.118/SC. Rel. Min. Luiz Fux. Primeira Turma. Dje 30/04/2008. 
Ressalta-se que o mercado das operadoras de planos de saúde (OPS) é bastante concentrado em cerca de $75 \%^{13}$ (setenta e cinco por cento) dos municípios do Brasil, estando acima do valor referencial mínimo, permite presumir de existência de poder de mercado. O elevado poder de compra das OPS pode produzir inúmeros efeitos deletérios para o bem-estar social, tal como a imposição de maiores preços aos consumidores. Alguns efeitos mais sutis merecem a consideração sobre a questão das cooperativas médicas. Por exemplo, a concentração do mercado de saúde suplementar também coloca as OPS em condições de impor remuneração menor aos profissionais da saúde. Na OPS capitalista, os honorários médicos constituem um custo que afeta o objetivo de lucro. Entretanto, a baixa remuneração dos médicos não é necessariamente um problema afeto apenas ao interesse individual entre eles e as sociedades que os credenciam para compor sua rede de atendimento. A remuneração precária também pode afetar o mercado setorial da saúde suplementar, na medida em que tende a produzir efeitos deletérios sobre a eficácia e a qualidade do atendimento dos utentes de planos de saúde (ALMEIDA; AZEVEDO, 2012, p. 181).

De todo modo, o poder de mercado das OPS para impor remuneração reduzida aos seus médicos conveniados ou associados constitui um fator preponderante para que estes se organizem em cooperativas de serviços especializados como forma de fortalecimento da capacidade de negociação e valorização dos seus honorários (MELO NETO; SILVA; LEANDRO, 2017).

Ocorre que, embora a doutrina reconheça que os diferentes arranjos cooperativos possam produzir efeitos pró-competitivos, beneficiando, inclusive, os consumidores, as cooperativas de especialidades médicas têm sido consideradas pela jurisprudência do $\mathrm{CADE}^{14}$, de forma preponderante, como cartéis de médicos (ALMEIDA, 2014, p. 73-80)' ${ }^{15}$.

13 Disponível em: <http://www.ans.gov.br/images/stories/Materiais_para_pesquisa/Materiais_ por_assunto/Dissertacoes_A_Regulacao_do_Mercado_de_SS_no_Brasil.pdf>. Acesso em: 19/09/2018.

14 Nesse sentido, um exemplar é a decisão final do Processo Administrativo 08012.004020/200464 - Representado: Conselho Regional de Medicina da Bahia; PA nº 08012.004372/2000-70 - Representada: Cooperativa de Otorrinolaringologia do Ceará - COORLECE, julgado em 27 de junho de 2002.

Disponível em: <https://sei.cade.gov.br/sei/modulos/pesquisa/md_pesq_processo_exibir.php? 2pXoYgv29q86Rn-fAe4ZUaXIR3v7-gVxEWL1 JeB-RtUgqOwvr6ZlwydIOIhRNSr2Q22IByVKByYDYwsa13_JxvvqWYGRw90R06rVGBSAeaB5HzbsrCTpWqDxglQWFw4N >. Acesso em: 18/09/2018.

15 O Governo norte-americano (Federal Trade Commission e U.S. Department of Justice) produziu o Antitrust Guidelines for Collaboration amanog Competitors, um guia para análise dos eventuais benefícios que podem resultar da cooperação entre competidores. Independente da inexistência de um guia análogo no Brasil, o CADE já reconhece em seus precedentes essa possibilidade a partir da análise econômica (ALMEIDA, 2014, p. 73). 


\section{Cooperação entre cooperativas - as concentrações como integração sistêmica das cooperativas.}

A inexistência de contradição a priori entre a cooperação típica das cooperativas e os interesses tutelados pelo Direito Antitruste pode ser analisada também em atos de cooperação entre sociedades cooperativas. Esses atos são tratados ao longo da construção da doutrina cooperativista como sendo representativos das diferentes práticas denominadas intercooperação ${ }^{16}$ (no caso das concentrações horizontais) ou como integração (no caso das concentrações verticais) ${ }^{17}$. Trata-se de uma estratégia que alicerçou a presença de cooperativas operadoras de planos de saúde, tanto médicos quanto odontológicos, em quase todo território nacional.

Waldírio Bulgarelli afırma que a concentração vertical e horizontal sistemática é bastante característica das cooperativas (1997, p. 60), e ela pode se dar sob distintas formas. Há atos de concentração específicos entre cooperativas previstas no próprio texto da lei (arts. 6 $8^{\circ}, 9^{\circ}$ e 79, da Lei $n^{\circ}$ 5.764/1971). Seu propósito é análogo ao que faz cooperarem as pessoas físicas dos cooperados no âmbito da sociedade, seja para superação dos desafios de baixa capitalização (LASSERRE, 1972, p. 117), seja como estratégia para racionalização de custos de transação ou até mesmo para ganho de escala, etc.

Vale lembrar que as cooperativas estão legalmente limitadas a manterem área de admissão de sócios limitada à capacidade de participação dos mesmos na vida social da cooperativa, de forma a viabilizar a participação de seus sócios trabalhadores e consumidores nas decisões da sociedade (art. $4^{\circ}$, inc. XI, da Lei $n^{\circ}$ 5.764/1971). É natural, portanto, que, ao invés de manterem estrutura centralizada típica de uma grande sociedade empresária, as sociedades cooperativas se estabelecem de forma descentralizada em diferentes localidades, interagindo economicamente entre si. Essa tendência à descentralização (ou pulverização) dos agentes envolvidos em redes de cooperativas pode ocorrer até mesmo por desmembramento, quando cooperativas atingem dimensões que dificultam o controle democrático pelos sócios (BULGARELLI, 1997, p. 60).

16 Constitui um dos sete princípios cooperativistas ("Co-operation among Co-operatives: Cooperatives serve their members most effectively and strengthen the co-operative movement by working together through local, national, regional and international structures."). Sobre os princípios cooperativistas v. em <http://ica.coop/en/whats-co-op/co-operative-identity-values-principles>. Acesso em 17/05/2018.

17 Nesse sentido, v., e.g., PINHO, 1997, p. 27-35 e DELGADO, 2017, p. 163-176. 
Além das cooperativas singulares ou de primeiro grau, constituídas predominantemente por pessoas físicas e destinadas à prestação direta de serviços aos associados (art. $6^{\circ}$, inc. I, e art. $7^{\circ}$, da Lei $n^{\circ}$ 5.764/1971), a lei prevê também as cooperativas constituídas por outras cooperativas (art. 6² inc. II e III, da Lei n 5.764/1971). Trata-se, nesse caso, das cooperativas de segundo ou terceiro graus, também denominadas federações (centrais) ou confederações, que têm por objeto organizar em comum e em maior escala os serviços econômicos e assistenciais do interesse de suas sócias. São hipóteses de concentração, tanto verticais quanto horizontais, que têm prévia previsão legal, e, por conseguinte, não podem ser compreendidas como práticas restritivas à concorrência.

Vergílio Périus (2001, p. 157-161) reforça que o conceito de ato cooperativo, previsto no art. 79 da Lei n 5.764/1971, reitera a licitude da concentração nas cooperativas, na medida em que contemplam a prática de atos entre cooperativas, quando associadas para consecução de seus objetivos sociais.

Por sua vez, Diva Benevides Pinho (1977, p. 27-35) afırma que a decisão de uma cooperativa se unir a outras em plano horizontal ou vertical representa a aceitação dessa sociedade a se submeter a regramentos coletivos de atuação sistêmica, em troca das vantagens que possam advir dessa concentração, tais como redução de custos, economia de escala, ampliação de serviços econômicos e sociais de interesse das cooperativas de primeiro grau, ampliação do mercado consumidor, defesa do produto das associadas, entre outros.

A cooperação entre cooperativas (intercooperação), a despeito de reforçar a modalidade de concentração natural do modelo econômico desse tipo específico de sociedade, reconhecida e fomentada por lei, não costuma suscitar problemas no campo da defesa da livre concorrência. Assim, com base nas hipóteses previstas na legislação citada acima, não há que se falar em condutas anticoncorrenciais praticadas pelas sociedades cooperativas, sejam elas de primeiro, de segundo ou de terceiro graus.

\section{Integração da análise antitruste pelo Direito Cooperativo.}

A livre iniciativa e livre concorrência não constituem um fim em si mesmo. Nem mesmo em sua origem, não consagram a liberdade econômica absoluta, de uma omissão absoluta do Estado em relação a iniciativa econômica privada. Na verdade, são liberdades submetidas a perspectiva constitucional de desenvolvimento (GRAU, 2015, p. 199-215). 
Com base na Constituição Federal de 1988, Eros Roberto Grau (IDEM, p. 205215) relaciona a livre concorrência como um dos princípios da ordem econômica para geração de desenvolvimento. Nesse contexto, afirma o autor ser este o objeto último da legislação antitruste, que teria caráter instrumental para sua promoção. É importante lembrar que o artigo $1^{\circ}$, da Constituição Federal, elenca, dentre os fundamentos da República Federativa do Brasil, os valores sociais tanto do trabalho quanto da livre iniciativa; e dentre seus objetivos, previstos no artigo $3^{\circ}$,garantir o desenvolvimento nacional.

Na verdade, a liberdade de iniciativa - que também se manifesta pela forma coletiva de produção da livre iniciativa cooperativista (IDEM, p. 200), trata-se de um norma geral que fundamenta a ordem econômica ao lado da valorização do trabaIho, mas que deve conviver de forma equalizada com os ditames da justiça social, equalizada pelos princípios destinados a dar cumprimento a essa ordem econômica, conforme art. 170 da Constituição Federal de 1988.

Dentre os princípios da Ordem Econômica Constitucional, textualmente são contemplados a soberania nacional, a propriedade privada e sua função social; a defesa do consumidor e do meio ambiente; a redução das desigualdades regionais e sociais. O caput deste mesmo artigo 170 estabelece que a valorização do trabalho humano, assim como a livre iniciativa são fundamentos dessa ordem.

Esse caráter instrumental outorgado pela Constituição do Brasil à livre iniciativa também se passa em relação à livre concorrência. Ambos devem promover a dignidade humana (GRAU; FOPRGIONI, 2005, p. 123). Mesmo antes da vigência da atual constituição, encontra-se na doutrina a sustentação de que a livre concorrência constitui "um valor-meio a servir o valor-fim, que vem a ser o bem comum e o interesse da coletividade" (GUERREIRO, 1987, p. 49).

Embora atos de concentração econômica possam, ocasionalmente, promover desenvolvimento, com base no princípio da livre concorrência o Estado busca evitar eventuais efeitos deletérios (BENFATTI, 2014). Trata-se de um dos instrumentos para transformar crescimento econômico em efetivo desenvolvimento econômico (IDEM, p. 181).

É, pois, justamente nesse mesmo Título VII (Da Ordem Econômica e Financeira) e nesse mesmo Capítulo I (Dos Princípios Gerais da Atividade Econômica) que a Constituição Federal vincula a regulação estatal em relação ao cooperativismo com uma expressa ordem de fomento (art. 174, § $2^{\circ}$ ). O motivo de tal comando é justamente a diferenciada vocação das cooperativas para geração de desenvolvimento.

Esta perspectiva constitucional de desenvolvimento talvez seja o principal elemento de diálogo entre as fontes do Direito Cooperativo e do Direito Concorrencial. 


\section{Cooperativismo e desenvolvimento - o diálogo das fontes.}

Conforme lições de Eros Grau (2015, p. 208-217), a Lei Antitruste procura prevenir e reprimir infrações contra a ordem econômica, submetendo-se a parâmetros constitucionais. De tal maneira, continua o autor, é necessário verificar se os comportamentos restritivos possuem ou não um efeito benéfico ou deletério para exercício da concorrência e, sobretudo, para o objetivo primordial do desenvolvimento nacional (cf. art. $3^{\circ}$, II, da Constituição Federal). Para este autor, o desenvolvimento constitui, assim, um princípio constitucional impositivo, uma norma-objetivo, dotado de caráter constitucionalmente conformador dos demais princípios da ordem econômica e deve conduzir a atividade econômica a "assegurar a todos uma existência digna, conforme os ditames da justiça social" (cf. art. 170, Constituição Federal.

Ainda segundo Eros Grau (2015, p. 213), de acordo com a ordem constitucional brasileira, desenvolvimento não significa mero crescimento econômico (seu aspecto quantitativo), mas também diz respeito ao progresso do bem estar social, de forma sustentada (seu aspecto qualitativo); um processo que concilia elevação do nível econômico e do nível cultural-intelectual comunitário, isto é, mudanças de ordem tanto quantitativa quanto qualitativa. Trata-se, portanto, na conclusão desse autor, de um processo de mobilidade social contínuo, de melhoria do nível econômico, cultural-intelectual e comunitário.

Sobre as condutas anticoncorrenciais, são repreendidas pela legislação antitruste aquelas caracterizadas a partir da análise da tríade ato, elemento volitivo e efeito (SALOMÃO FILHO, 2013, p. 399-400). O art. 36, caput, da Lei n 12.529/2011, prioriza o controle contra os abusos do poder econômico, sendo, portanto, valorizada a análise dos atos de concentração por seus efeitos potencialmente restritivos à concorrência (FORGIONI, 2015, p. 142-143).

Nesse contexto, cabe analisar os efeitos esperados, em geral, de atos de cooperação nas cooperativas. Na verdade, eles são, em regra, pró-competitivos e geradores diferenciados de desenvolvimento. A cooperação típica que se manifesta nas cooperativas não está, sob o ponto de vista ontológico, vocacionada para produção de efeitos restritivos da concorrência ou para produção de infrações à ordem econômica. Ao contrário, além de tender à ampliação da concorrência, influenciando preços, alinha-se aos objetivos estatais como geradora de desenvolvimento.

Sob uma perspectiva ampla, Dieter Benecke (1980, p. 109-134) arrola resultados esperados da cooperação própria das cooperativas, especialmente nos países em desenvolvimento. No plano meta econômico, espera-se o incremento do nível 
cultural e intelectual/educacional para um comportamento solidário e democrático. No campo da realização dos interesses individuais dos sócios das cooperativas, se espera o aumento da renda e da formação de poupança; melhoramento no nível de informação, possibilidade de ascensão social. E, sob o aspecto macroeconômico, as cooperativas geram influências positivas sobre o sistema econômico, na mudança na distribuição de renda, superação do desprovimento e aceleração do crescimento econômico. Ao arrolar os elementos que caracterizam o comportamento de cooperação manifestado nas cooperativas, o mesmo autor utiliza a expressão "cooperação cooperativa" para distingui-lo, como tipologia própria, de outras formas de cooperação (IDEM, p. 82).

Comparando a atividade cooperativista com a atividade empresarial (com finalidade lucrativa), também se identifica que não preponderam os riscos de superprodução ou infra produção, dado que o princípio econômico de cooperação por meio de cooperativas (ou "cooperação cooperativa", como prefere Dieter Benecke) tem por finalidade atender às necessidades de consumidores que participam da decisão sobre a demanda própria, buscando equilíbrio entre qualidade com menores preços (WEBASSE, 1945, 225-226).

A percepção do diferencial esperado também é ressaltada por Paula Forgioni que destaca a estratégia do incentivo às cooperativas como política pública apta e destinada a "estimular a criação e a sobrevivência de 'células corretoras' do sistema capitalista" além de "fertilizar mecanismos de coesão social" (FORGIONI, 2014, p. 65).

A função corretora do cooperativismo sobre as distorções sociais do capitalismo é, de longa data, historiada pela doutrina cooperativista (v. p. ex. MLADENATZ, 2003), mas para além de instrumento de correção, o cooperativismo é acreditado também como um idealizado caminho para a emancipação pacífica do consumidor e do trabalhador (GIDE, 2008, p. 54-66). Ao contrário de indiciar tendência de violação concorrencial, as cooperativas sempre foram identificadas pela vocação contrária, qual seja, a de combater os cartéis e trustes (LASSERRE, 1956).

Acerca da análise de eficiência, identificar-se-ia tal diferencial nas cooperativas. Embora parte da doutrina demonstre o declínio da primazia da Escola de Chicago e, portanto, da concepção de eficiência econômica como principal objetivo do Direito Antitruste (SALOMÃO FILHO, 2013, p. 446), é cabível uma consideração sobre a cooperação como comportamento apto a proporcionar maior eficiência econômica e social que interações puramente competitivas para a realização de interesses individualistas.

O autor (2012, p. 26-43) destaca ainda o dilema comportamental e cultural entre individualismo e cooperativismo. Reconhece que a cooperação econômica deve ser 
contemplada como uma política regulatória de fomento; que o Direito venha a cumprir o papel fundamental de impulsioná-la, a fim de que seja facilitado um processo de escolha individual e consciente dos indivíduos, qual seja o de adotar o comportamento cooperativo como forma de realização mais vantajosa de interesses individuais através da realização dos interesses coletivos comuns daquelas que cooperam entre si para um mesmo objetivo e para o bem estar social.

Apesar de existirem inúmeras condicionantes que impõem a necessidade de instituições e a incorporação social de valores que induzam a cooperação, o desenvolvimento justificaria um esforço pelo Direito e pela atividade regulatória nesse sentido. Ainda segundo o autor, o cooperativismo constitui um princípio básico de uma teoria jurídica do desenvolvimento, relacionada à ideia de democracia econômica e de realização de algo que o Estado deve fazer e que o mercado e o particular jamais farão espontaneamente: redistribuir riqueza (como princípio da ordem econômica, de acordo com o art. 170, inciso VII, da Constituição Federal).

De acordo com a Teoria dos Jogos, que analisa os resultados obtidos entre diferentes interações estratégicas por comportamento cooperativos ou competitivos, quando diferentes atores podem estabelecer compromissos e garantias efetivas de cumprimento desses compromissos, se está diante de um jogo cooperativo. A possibilidade de melhor realização de interesses individuais através de comportamento de cooperação coletiva se concretizaria através da produção de resultados coletivos mais eficientes (FIANI, 1961, p. 110-111).

Esse método de ajuste prévio e de garantias das condições para cooperação entre os diferentes membros das cooperativas se dá também por meio de "relações organizacionais pré-determinadas" (BENECKE, 1980, p. 84). É importante que essa interação de cooperação seja estimulada nas cooperativas em prol do aumento de eficiência econômica esperado nas cooperativas. As garantias servem para produzir a confiança necessária para a cooperação se instalar (LASSERRE, 1972, p. 119). A psicologia tem um importante papel a cumprir nesses cenários, a fim de estimular uma cooperação voluntária e espontânea (AXELROD, 2010). O que se vê é que o exercício da cooperação envolve uma evolução do comportamento social. Nesse contexto, os estatutos, assembleias gerais e normas infra estatutárias das cooperativas constituem importantes instrumentos autogestionários para regulação ou estímulo do comportamento de cooperação entre membros de cooperativas.

Outro aspecto diz respeito à questão de admissão de sócios nas cooperativas. No Brasil (art. 4 , inciso XII, da Lei $n^{\circ}$ 5.764/1971, que definiu a Política Nacional de Cooperativismo), a admissão de cooperados tem uma limitação territorial, visando preservar a capacidade de reunião e participação dos mesmos no centro decisório 
do empreendimento. Por consequência, contribui-se para o desenvolvimento local onde se instala a cooperativa, pois o resultado econômico não é distribuído a sócios meramente investidores e sem vinculação com o local de atuação da sociedade cooperativa. Além de não distribuir excedentes ao capital estrangeiro, a riqueza produzida permanece especialmente nessas localidades.

A democratização da iniciativa privada também é um diferencial das cooperativas (v. BECHO, 2002, p. 132-135; WERBASSE, 1945). A união de trabalhadores ou consumidores num empreendimento cooperativista permite que assumam o papel de titulares da atividade econômica desenvolvida. Isso porque, reúnem-se, na mesma pessoa do sócio, dois papéis (titular do empreendimento e cliente/usuário) que no modelo de mercado capitalista estariam em polos e com interesses opostos. A sociedade empresária (como empreendimento capitalista) tende a remunerar o mínimo possível o trabalhador, já que remuneração é fator de custo que diminui o lucro, ou tende ainda a vender ao consumidor pelo maior preço possível, visando aumentar o lucro.

Essa dinâmica pretende proporcionar a prática do preço justo (BULGARELLI, 2000, p. 21) para o cooperador - a melhor remuneração do trabalho extraível do empreendimento ou o melhor produto ou serviço com o menor custo possível. Tal objetivo, que era defendido por Charles Gide (IDEM, p. 93), seria incompatível com a finalidade do empreendimento capitalista.

No cooperativismo, consumidores e trabalhadores, sócios da sociedade cooperativa, participam das deliberações, independentemente da proporção do seu quinhão social (i.e. do tamanho da sua participação no capital na sociedade), exercendo qualquer deles o mesmo peso de voto - "singularidade de voto" (cf. art. $4^{\circ}$, inciso V, da Lei n 5.764/1971, e art. 1.094, inciso VI, do Código Civil) - o que também implica na democratização da iniciativa privada (WARBASSE, 1975, p. 172-192).

Além disso, cooperativas são a única espécie societária que, nas distintas legislações, costumam ter obrigação de constituir um fundo que será provido com parte de seus resultados e que será revertido de forma indivisível para todo quadro social, através de serviços ou assistência técnica, social e educacional. No Brasil, trata-se do Fundo de Assistência Técnica, Educacional e Social (art. 28, caput, inciso II, da Lei n 5.764/1971).

Finalmente, mas não esgotando o tema, outro aspecto diz respeito à forma de distribuição dos eventuais superávits produzidos pela cooperativa. A distribuição do excedente do exercício social (distribuição dos resultados apurados no exercício social) não é feita na medida da participação de cada sócio no capital social (como é comum entre os demais tipos societários), mas na razão de sua participação nos 
negócios que produziram o excedente (i.e. proporcionalmente ao valor das operações efetuadas pelo sócio com a sociedade cooperativa, cf. art. $4^{\circ}$, inciso VII, da Lei $n^{\circ}$ 5.764/1971, e art. 1.094, inciso VII, do Código Civil). Trata-se da característica do retorno (BULGARELLI, 2000, p. 160-162), que consolida nas cooperativas a justiça distributiva. Valoriza-se a atuação do indivíduo e não sua capacidade de investimento (afastando a figura do sócio meramente investidor), proporcionando-se distribuição mais eficiente dos excedentes, ao invés de concentração de riqueza.

A construção ensaiada até aqui não poderia ter pretensões de sugerir fórmulas vinculativas ou roteiros afirmativos de uma análise concorrencial da atuação das cooperativas, não só porque está limitada pelo propósito deste trabalho, mas, especialmente, diante do reconhecimento dos inúmeros riscos da formulação de métodos ou predições por meio de modelos quantitativos e especulativos em matéria econômica (ANDRADE, 2014, p. 429-183).

A rigor, há, por um lado, diferentes métodos que têm por objetivo colaborar com o estabelecimento de padrões de aplicação, reforma e produção de uma legislação cooperativista ou que dialogue com ela de forma a manter a identidade das cooperativas $^{18}$. Por outro lado, este trabalho não poderia abordar extensivamente as inúmeras contribuições que o Direito Cooperativo possa aportar ao diálogo com outros ramos do Direito e com o Direito Concorrencial em particular. Portanto, procuramos sistematizar os parâmetros adiante expostos e identificar em seguida um importante elemento constitucional para o diálogo das fontes.

\section{Vetores estruturais.}

Rui Namorado (2000, p. 14) entende as cooperativas como uma estrutura econômica que corresponde a uma forma jurídica e sugere que essa estrutura está vocacionada para a produção de patamares superiores de desenvolvimento. Doravante, as componentes dessa estrutura devem ser consideradas na análise antitruste como regulares e típicas de uma forma de exercício de atividade econômica lícita, fundada na cooperação.

Do contrário, além do risco de o Estado promover a descaraterização e o desestímulo do cooperativismo por meio da atuação da autoridade antitruste, pode restar ameaçada a oportunidade de desenvolvimento socioeconômico sustentável que ele representa.

18 Por exemplo, veja-se no âmbito do Direito Cooperativo europeu, a proposta representada pela construção dos Princípios Europeus de Direito Cooperativo -PECOL (HIEZ, 2017, p. 11-15). No âmbito da América Latina, veja, por exemplo, uma proposta para uma nova estruturação constitucional para as cooperativas no Estado Socialista de Cuba (MUSA, 2017). 
Max Weber menciona a necessidade de as normas jurídicas deverem ser tanto consequência quanto causa das regularidades das ações humanas e de tipos empíricos. De tal maneira, a práxis cooperativista, ao longo do tempo, teria se desenvolvido de um costume para uma tipologia empírica que, posteriormente, foi recepcionada em normas que guardassem as garantias jurídicas de seu funcionamento (2000, vol. 1, p. 223).

Esteban Balay (1965, p. 14-15) afirma que os princípios e métodos de qualquer sistema não são inventados por ninguém, são descobertos por prévia observação e análise científica dos fatos econômicos e sociais dos indivíduos e das suas instituições. De tal maneira, o que diferentes autores identificam como fatos estruturantes da tipologia das cooperativas constituem o que pode ser denominado como vetores estruturais das cooperativas. Eles funcionam para verificar se a iniciativa regulatória ou legislativa seria congruente para reforçar o adequado funcionamento das cooperativas ou, ao revés, a sua descaraterização.

A cooperação, enquanto comportamento, por si só não constitui uma característica exclusiva das cooperativas, embora, como visto, se manifeste nelas como um elemento essencial e estruturante de sua tipologia (GAUDIO, 2016, p. 553-555).

No caso específico das cooperativas de saúde, o que qualifica esse comportamento preordenado de cooperação entre os profissionais da área de saúde são dois outros fatos que caracterizam a cooperação nas cooperativas.

Primeiramente, há o fato de que esses trabalhadores não são apenas profissionais que serão contratados pela operadora de planos de saúde, representando para estas um custo da exploração do mercado de planos de saúde. Nas operadoras de planos de saúde, estruturadas como cooperativas, esses médicos e dentistas serão obrigatoriamente donos da cooperativa (sócios).

É estabelecida entre cooperado e cooperativas uma relação jurídica dúplice e incindível - societária e operacional (negocial). De tal maneira, os associados somente poderão ser sócios para manter com as cooperativas relações negociais vinculadas à atividade econômica que constitui seu objeto, assim como só poderão estabelecer tais negócios na condição de sócios. De longa data, essa particularidade, denominada "dupla qualidade" (BULGARELLI, 2000, p. 21), tem sido considerada como um elemento que identifica e diferencia a cooperação nas cooperativas e que distingue estas de outras pessoas jurídicas (LANG-WEIDMÜLLER, 1951, p. 28 cit. por FRANK,1978, p. 160, BENECKE, 1980, p. 84; LASSERRE, 1972, p. 14).

$\mathrm{O}$ segundo elemento diz respeito à finalidade das cooperativas, que, independentemente de seu objeto (atividade exercida) será semprea de prestar serviços aos sócios para melhorar suas condições socioeconômicas (FRANK, 1973, p. 15-17). 
É o que prevê também o art. $4^{\circ}$, inciso X, da Lei n 5.764/1971. Para tanto, atribui-se ao capital um caráter meramente instrumental; para dar viabilidade ao empreendimento coletivo dos trabalhadores e consumidores convertidos em sócios - e não de explorar a atividade econômica no sentido de remuneração (retorno) ao capital investido (fım lucrativo). Otto von Gierke (1990, p. 215-229) reconhece a finalidade própria das cooperativas como um elemento que as caracteriza ontologicamente no processo histórico de construção do modelo.

A interação entre esses elementos pode ser constatada no caso dos médicos e dentistas que buscam se fortalecer contra as pressões do capital especulativo em busca de melhor remuneração, qualidade de condições gerais de trabalho e distribuição de riqueza.

Tal característica essencial evidencia que a cooperação nas cooperativas não tem, ao menos do ponto de vista estrutural, finalidade colusiva e, portanto, anticoncorrencial. Ao contrário, como visto, se alinha aos fundamentos e objetivos fundamentais da República, assim como os objetivos e fundamentos da ordem econômica (artigos $1^{\circ}, 3^{\circ}$ e 170 da Constituição Federal).

Assim sendo, a análise antitruste deve considerar que o comportamento de cooperação econômica é natural nas cooperativas, caraterizado pela dupla qualidade e pela finalidade das cooperativas. Essa trilogia estrutural, que confere identidade a essas sociedades, impede que a cooperação entre sócios de cooperativas possa ser reputada como ilícitos anticoncorrenciais per se. Ao contrário, a única presunção coerente é a geração de desenvolvimento e de efeitos pró-competitivos.

Como visto, além desses parâmetros estruturais estarem aptos a informar o Direito da Concorrência, eles foram recepcionados na Constituição Federal de 1988 sob três parâmetros que devem pautar o Estado, inclusive através da regulação do mercado da saúde suplementar e da própria concorrência: um comportamento de cooperação econômica típico (cooperação cooperativista), dupla qualidade e finalidade de prestar serviços ao consumidor ou trabalhador cooperado, sem caráter especulativo, para incrementar sua situação socioeconômica (finalidade própria).

\section{Vetores constitucionais.}

Especificamente quanto aos seus parâmetros constitucionais, o Brasil está entre os países que têm uma base constitucional para o cooperativismo, especialmente desde que o ambiente democrático se restabeleceu em 1988. A Constituição Federal afırma parâmetros que vinculam o Estado a uma política pública bastante clara, mas ainda pouco respeitada. 
É possível identificar a forte relação entre esses vetores constitucionais e direitos fundamentais - o que ratifica a importância de que devam orientar a autoridade antitruste, quais sejam liberdade, fomento e regime jurídico adequado (artigos $5^{\circ}$, inc. XVII; 146, inc. III, "c" e 174, § $2^{\circ}$ da Constituição Federal) (MEINEN; GAUDIO, 2015, p. 143-147).

Quanto à liberdade, reforça essa previsão a presunção de regularidade da cooperação como manifestação de uma livre iniciativa própria, constitucionalmente reconhecida, permitindo a compreensão de uma legalidade apriorística de comportamento de autodefesa econômica do consumidor e do trabalhador, ao invés de uma colusão. O artigo 50, inciso XVIII, da Constituição Federal, declara, sob a perspectiva econômica, a liberdade de constituição e funcionamento das cooperativas e proíbe, na forma da lei, a interferência estatal. O Direito Econômico reconhece a "livre iniciativa cooperativa" como uma das diferentes manifestações da iniciativa livre. Portanto, essa forma de atividade econômica deve estar sujeita ao mesmo regime de liberdade reconhecido a outras formas de inserção no mercado, como a empresa capitalista (GRAU, 2015, p. 199-201). Trata-se do direito dos indivíduos, como trabalhadores ou consumidores, de realizar suas aspirações no campo do trabalho e do consumo, através de uma empresa própria. Trata-se de uma dimensão direito fundamental de liberdade.

Quanto ao regime jurídico adequado, é necessário reconhecer uma lógica de causalidade estrutural entre as peculiaridades próprias do modelo cooperativista de ordenar os elementos de produção e um regime jurídico original. Em nível constitucional, foi o constituinte cauteloso em explicitar a exigência de uma lei específica para tratar de um regime tributário congruente com o diferencial dessa forma de exercer atividade econômica. Nesse sentido, o artigo 146, inciso III, "c", da Constituição Federal, utiliza a expressão "adequado tratamento tributário".

Ao reconhecer a necessidade de um regime tributário adaptado, a Constituição Federal evidencia que o Estado é obrigado a exercer um tratamento isonômico para as cooperativas. Significa, é claro, que essas sociedades terão um regime legal compatível com suas diferenças intrínsecas e terão um tratamento indistinto no que equivale à empresa capitalista ou outras estruturas de exercício de atividade econômica. Estamos no campo do direito fundamental da igualdade, portanto. Ao invés de representar uma violação da igualdade de tratamento, a produção de legislação adaptada ao diferencial estrutural da cooperativa é uma diretriz que promove igualdade (TORRES, 2013, p. 1603). Em linha análoga, o reconhecimento desses vetores não escapou à leitura crítica de Ingo Sarlet (2012, p. 26-27), que defende a articulação de um regime diferenciado para as cooperativas a partir do plano constitucional. 
Quanto ao fomento, vale ressaltar, a atribuição de determinadas prerrogativas ${ }^{19}$ às cooperativas não induz uma inconstitucionalidade no campo da isonomia, sobretudo quando o próprio texto constitucional estatui tal tratamento ${ }^{20}$ (ARAGÃO, 2013, p. 1833). A rigor, o que ocorre é similar ao tratamento favorecido para as empresas de pequeno porte (cf.inc. IX do art. 170, da Constituição Federal) embora os fundamentos para as cooperativas sejam de mais escol21. Esse vetor se relaciona como uma prerrogativa do setor, mas, especialmente, como uma prescrição de interesse do próprio Estado para promoção de políticas de desenvolvimento.

A Constituição impõe ao legislador, no artigo 174, § $2^{\circ}$, uma indução positiva. Este parâmetro é observado em diferentes textos constitucionais de diferentes países. Considerando a vocação das cooperativas para produzir melhores níveis de desenvolvimento socioeconômico sustentável, deve ser do interesse do Estado promover a atividade cooperativa. Essa ordem de apoio e incentivo às cooperativas é justificada pelo alinhamento entre o propósito das cooperativas, os objetivos da ordem econômica constitucional brasileira e os objetivos e fundamentos da própria República (GAUDIO, 2016, p. 519-544). Trata-se de um mecanismo de intervenção estatal por indução, modalidade de atuação estatal que, quando manifestada por lei ou ato normativo, não raro é questionada em sua constitucionalidade (GRAU, 2015, p. 143-145).

Assim sendo, a Constituição Federal estabelece três parâmetros para integração da atividade cooperativista com a defesa da livre concorrência: a liberdade da atividade cooperativista, a obrigação estatal de apoio e estímulo (fomento para geração de desenvolvimento) e de tratá-la de forma congruente com seu diferencial estrutural próprio (isonomia).

19 Com base em fundamentos econômicos, a Constituição Federal reconhece, por exemplo, o tratamento diferenciado e favorecido às microempresas e empresas de pequeno porte (art. 146, III, "d"; 179), inclusive quanto à tributação (art. 94) e outras relações obrigacionais (art. 47 , inc. I).

20 Art. 174. Como agente normativo e regulador da atividade econômica, o Estado exercerá, na forma da lei, as funções de fiscalização, incentivo e planejamento, sendo este determinante para o setor público e indicativo para o setor privado. (...) $\S 2^{\circ}$ - A lei apoiará e estimulará o cooperativismo e outras formas de associativismo." (destacou-se)

21 Nesse contexto, cite-se a ilustrativa previsão de favorecimento dirigido às cooperativas no art. 34 da Lei 11.488/2007, materialmente prevendo mesmo favorecimento outorgado às pequenas e microempresas. 0 dispositivo que estende as vantagens conferidas às microempresas e empresas de pequeno porte às cooperativas: "Art. 34. Aplica-se às sociedades cooperativas que tenham auferido, no ano-calendário anterior, receita bruta até o limite definido no inciso II do caput do art. $3^{\circ}$ da Lei Complementar $n^{\circ} 123$, de 14 de dezembro de 2006, nela incluídos os atos cooperados e não-cooperados, o disposto nos Capítulos V a X, na Seção IV do Capítulo XI, e no Capítulo XII da referida Lei Complementar." 


\section{Cooperativismo e análise antitruste pelos efeitos.}

Feitas as oportunas advertências sobre o não cabimento de predições ou roteiros dogmáticos em matéria econômica, parece-nos possível afirmar ter sido demonstrado que o Direito Cooperativo possui contributos próprios a serem somados ao elenco de instrumentos das possíveis análises antitruste, refinando ainda mais a defesa dos interesses instrumentais da defesa da concorrência. Por essa razão, escolhemos o uso da expressão "vetores" ao trabalhar a ideia de influências constitucionais e estruturais para a análise antitruste da cooperação cooperativista.

De toda forma, tornando a utilizar o consolidado cenário da unimilitância e das cooperativas de especialidades médicas como demonstração da proposta de integração entre Direito Cooperativo e Direito da Concorrência, parece-nos que a atual jurisprudência (judicial e administrativa) e regulação normativa do cooperativismo na área da saúde podem comportar importantes temperos no plano da aplicação das válvulas de escape.

Ainda que se considere que determinadas formas de estabelecimento da cooperação nas cooperativas constituam uma restrição à concorrência, diante da vocação das cooperativas para a produção de efeitos concorrenciais ou de efeitos geradores de desenvolvimento, é importante utilizar os "instrumentos destinados a evitar que a tutela da concorrência venha a desempenhar função oposta àquela desejada"- esses instrumentos são as válvulas de escape da legislação antitruste (FORGIONI, 2015, p. 193).

Considerando que o objetivo do antitruste seja o próprio desenvolvimento (SALOMÃOFILHO, 2012, p. 45-105) eque, em contrapartida, a vocação das cooperativas para sua geração é desafiada pelo desconhecimento de suas particularidades e pela racionalidade econômica hegemônica, é válida uma leitura das válvulas de escape atenta às especificidades das cooperativas.

No caso da unimilitância, a peremptória vedação feita, no Brasil, por meio de norma regulatória da Agência Nacional de Saúde Suplementar (ANS) não considera, por exemplo, que em determinados mercados relevantes (sob o ponto de vista geográfico) as cláusulas de exclusividade não produzam poder de mercado. Em grandes municípios do Brasil, o serviço de saúde tende à elasticidade, dado a oferta de inúmeros planos de saúde de diferentes OPS, além da ampla quantidade de especialistas para composição de suas redes de atendimento.

Nas grandes regiões metropolitanas do país, a unimilitância dificilmente comprometeria a formação de rede de atendimento por parte de outras OPS. A norma regulatória não prevê exceções para análise in concreto sobre a existência ou não de 
efeitos anticoncorrenciais, embora até mesmo efeitos pró-competitivos possam se configurar nesses mercados relevantes.

Igualmente, a oferta de outros especialistas nesses mercados geograficamente relevantes dificilmente impediria a contratação de profissionais que não estivessem vinculados às cooperativas.

Cabe considerar a especialidade das isenções setoriais, em bloco, sendo o setor cooperativista regido por arcabouço legislativo especial, compatível com o regime jurídico que lhe deve ser próprio, tal como indiciam os vetores estruturais e constitucionais. Isso porque, o sistema de leis especiais que emergem da base constitucional das cooperativas é formado pelos dispositivos específicos do Código Civil, da Lei Geral de Cooperativas (Lei n 5.764/1971) e de leis especiais de regência das cooperativas financeiras (Lei Complementar $n^{\circ}$ 130/2009) e de trabalho (Lei $n^{\circ}$ 12.690/2012). Paula Forgioni (2015, p. 201-211) ressalta que a antinomia entre o regime especial de microssistemas e o regime geral do Direito Concorrencial (Lei $n^{\circ}$ 12.529/2011) deve, o quanto possível, ser considerada aparente, produzindo-se a harmonização necessária.

Nesse campo, a ponderação (jogo) dos interesses protegidos merece sofrer influência na análise concreta a partir dos diferenciais específicos das cooperativas, com base especialmente em seu caráter instrumental para cumprimento dos objetivos da ordem econômica. Os arranjos cooperativos devem ser analisados sob os preceitos da "regra da razão" - de forma a sistematizar um acordo social, de maneira que, se os ganhos de eficiência compensarem os efeitos negativos do aumento do poder de mercado, a prática deve ser aceita pela autoridade de defesa da concorrência (ALMEIDA; AZEVEDO, 2012, p. 169).

\section{Considerações finais.}

A respeito do que foi tratado, mesmo reconhecendo a insuficiência da produção científica em matéria de cooperativismo, pretendemos demonstrar que a cooperação cooperativista não deve ser encarada como um ilícito anticoncorrencial por si só. Isso se reflete tanto na impossibilidade de tal presunção específica quanto ao abuso de poder econômico na unimilitância das OPS cooperativas, incluindo a não presunção de cartelização de médicos em cooperativas de serviços especializados, e também nos diferentes e praticamente inquestionados atos de concentração por integrações e intercooperações entre cooperativas.

De todo modo, merece ser considerada, na análise antitruste, a utilização de vetores estruturais e constitucionais próprios desse setor representado pelo modelo 
cooperativista, como forma de harmonização do sistema geral da defesa da livre concorrência e do sistema jurídico especial das cooperativas.

Os parâmetros econômicos estruturais para análise são a própria cooperação econômica como elemento típico das cooperativas (cooperação cooperativista), qualificado pelos parâmetros da dupla qualidade e da finalidade específıca das cooperativas. Os parâmetros constitucionais desse sistema são a liberdade, a isonomia e o fomento à atividade cooperativista.

Nesse contexto, reconhecido o interesse instrumental da ordem econômica na geração de desenvolvimento e a vocação das cooperativas para realização desse interesse constituem pedra de toque não só para a equalização entre cooperativismo e antitruste, mas para a conformação de políticas públicas de desenvolvimento através das cooperativas, inclusive em cumprimento ao vetor constitucional de fomento ao setor.

Assim, o mecanismo das válvulas de escape e a ponderação dos interesses protegidos a partir dos efeitos da cooperação cooperativista encontram, no perfil do modelo jurídico e econômico das cooperativas, importantes elementos para aperfeiçoar a tutela concorrencial.

\section{Referências bibliográficas.}

ALMEIDA, S. F. de. (2014). Efeitos concorrenciais das cooperativas médicas. In: Congreso Continental de Derecho Cooperativo. CRACOGNA, Dante (coord.), Ciudad Autónoma de Buenos Aires: Intercoop.

ANDRADE. J. M. A. de. (2014). Economicização do Direito Concorrencial. São Paulo: Quartier Latin.

ANDRIGHI, F. N. (2005). A autonomia do Direito Cooperativo. In: KRUEGER, Guilherme (coord.) Cooperativismo e o novo Código Civil. $2^{\mathrm{a}}$ ed., Belo Horizonte: Mandamentos.

ARAGÃO, A. S. de. (2013). Comentário ao art. 174, § 2º. In. CANOTILHO, J.J. G., MENDES, G. F., SARLET, I. W. e STRECK, L. (Coords.). Comentários à Constituição Federal do Brasil. São Paulo: Saraiva/Almedina.

AZEVEDO, P. F. de. (2008). Cooperativas e defesa da concorrência. In: Cooperativas na ordem econômica constitucional: cooperativas, concorrência e consumidor: tomo II. KRUEGR, G. (coord). Belo Horizonte: Mandamentos. 
AZEVEDO, P. F. de; ALMEIDA, S. F. de. (2012). Cooperativas médicas: cartel ou legítima defesa? In: Cooperativas na ordem econômica constitucional: cooperativas, concorrência e consumidor: tomo II. KRUEGR, G. (coord). Belo Horizonte: Mandamentos.

AXELROD, R. (2010). A evolução da cooperação. São Paulo: Leopardo.

BALAY, E. (1965). Bases del ordenamento cooperativo de la economia social. Buenos Aires.

BAGNOLI, V., BASTOS, A. A. R. e NAVAS, A. R. E. (2014). Cláusulas de exclusividade - análise concorrencial a partir do caso dos créditos consignados. São Paulo: Almedina.

BECHO, R. L. (2002). Elementos de Direito Cooperativo (de acordo com o Código Civil). São Paulo: Dialética.

BENECKE W. (1980). Cooperação e desenvolvimento. O papel das cooperativas no processo de desenvolvimento econômico nos países de Terceiro Mundo. Porto Alegre: Coorjornal.

BENFATTI, F. F. N. (2014). Direito ao desenvolvimento. São Paulo: Saraiva.

BORBA, J. E. T. (2015). Direito societário. 14ª ed. São Paulo: Atlas.

BULGARELLI, W. (2000). Elaboração do Direito Cooperativo. São Paulo: Atlas, 1967.

. As sociedades cooperativas e sua disciplina jurídica. $2^{\mathrm{a}}$ ed., Rio de Janeiro: Renovar. . (1997) Concentração de empresas e direito antitruste. São Paulo: Atlas.

CONTO, M. de. (2012). A cláusula de exclusividade nos estatutos sociais das cooperativas no direito brasileiro: direitos fundamentais e relações privadas. In: MEIRA, Deolinda (coord). A jurisprudência cooperativa comentada - obra de comentários a acórdãos da jurisprudência portuguesa, brasileira e espanhola. Lisboa: INCM.

CRACOGNA, D. (2008). Cooperativismo y universidad: passado y presente. In: SOLER, Henrique

Gadea. Boletín de la Asociación Internacional de Derecho Cooperativo (BAIDC), n42 - universidady cooperativismo. Bilbao: Deusto Publicaciones.

CUEVA, R. V. B. (2008). Cooperativas médicas e concorrência na jurisprudência do CADE: In KRUEGER, G. (coord). Cooperativas na ordem econômica constitucional. T. II. Mandamentos, Belo Horizonte. 
FORGIONI, P. (2014). As sociedades cooperativas no Brasil: muito além dos preconceitos e das questões tributárias. In: CRACOGNA, D. (coord.), Congreso Coninental de Derecho Cooperativo. Ciudad Autónoma de Buenos Aires: Intercoop. . (2015). Os fundamentos do antitruste. $8^{\text {a }}$ ed. São Paulo: Editora Revista dos Tribunais.

FRANK, W. Direito das Sociedades Cooperativas. São Paulo: Saraiva.

GAUDIO, R. (2014). Marco Legal brasileiro das cooperativas de trabalho: busca pelo direito adequado em meio ao discurso jurídico reacionário. In: Congreso Continental de Derecho Cooperativo. CRACOGNA, Dante (coord.), Ciudad Autónoma de Buenos Aires: Intercoop.

. e FARIAS, E. H. de. B. (2014). Da razão indolente ao Cooperativismo: violação e incompreensão das características essenciais das sociedades cooperativas como fatores de prejuízo socioeconômico. Artigo in Anais do $4^{\circ}$ Seminário Interdisciplinar em Sociologia e Direito. Niterói: Ed. PPGSD-UFF, p. 49/51. Disponível em <http://sociologiaedireito.com/wp-content/ uploads/2015/01/GT7.pdf>. Acesso em 17/05/2018.

. (2016). Desenvolvimento econômico e cooperativismo: fundamentos e desafios para implementação do art. 174 , $\$ 2^{\circ}$, da Constituição Federal, a partir das características essenciais das sociedades cooperativas. In: MIRANDA, J. E.; REIS, M. T.; GAUDIO, R.; SIELICHOW, C.d.S. (coord). Ordem econômica constitucional: compreensão e comparativo da ordem econômica na Constituição de 1988 com outros sistemas jurídicos. Curitiba: Juruá.

GIDE, C. (2008). O cooperativismo. Brasil: Confebrás.

GRAU, E. R.; FORGIONI, P. (2005). O estado, a empresa e o contrato. São Paulo: Malheiros, 2005.

GRAU, E. R. (2015). A ordem econômica na constituição de 1988. $17^{a}$ ed., São Paulo: Malheiros.

GREMAUD, A. P. e BRAGA, M. B. (1998). Teoria dos Jogos: Uma Introdução. In: PINHO, Diva Benevides e VASCONCELLOS, Marco Antônio Sandoval de (org.). Manual de Economia. $3^{\text {a }}$ ed., São Paulo: Saraiva.

GUERREIRO, J. A. T. (1987). Formas de abuso do poder econômico. Revista de Direito Mercantil, Industrial, Econômico e Financeiro, ano XXVI (nova série), n. 66, p. 49. São Paulo: RT, abr.-jun. 
HIEZ, D. (2017). Introduction. In: FAJARDO, G., FICI, A., HENRŸ, Hagen., HIEZ, D., MEIRA, Deolinda., MÜNKNER, H., SNAITH, I. Principles of european cooperative law. Pinciples, commentaries and national reports. Cambridge: Intersentia.

JOHANNEN, U. (1973). Apresentação da obra de PINHO, Diva Benevides (coord.). A problemática cooperativista no desenvolvimento econômico. São Paulo: GG Artegráfica.

KRUEGER, G. (2016). Cooperação, concorrência e colusão. Os casos de cooperativas de anestesiologistas com domínio de mercado no Brasil. CIRIEC-España. Revista Jurídica Nº 26/2015. Disponível em www.ciriec-revistajuridica.es. Acesso em 17/05/2018.

LASSERRE, G. (1956). Coopératives contre cartels et trusts. Paris: Deuxieme edition. . (1972). El Cooperativismo. Barcelona: Oikos-tau.

MACKAAY, E. (2015); ROUSSEAU, S. Análise econômica do Direito. $2^{a}$ ed., São Paulo: Atlas.

MEINEN, E. e GAUDIO, R. (2016). Sobre o diferencial estrutural e desafios das instituições financeiras cooperativas no ambiente regulatório brasileiro. In: Boletín de la Asociación Internacional de Derecho Cooperativo, $n^{\circ} 49$ - sistemas de crédito cooperativo. Bilbao: Universidad de Deusto.

NETTO, A. M. M.; SILVA, A. L. da.; LEANDRO, T. (2012). CBHPM: A conciliação entre a livre concorrência e a defesa da dignidade médica é possível? In: Cooperativas na ordem econômica constitucional: cooperativas, concorrência e consumidor: tomo II. KRUEGR, G. (coord). Belo Horizonte: Mandamentos.

MLADENATZ, G. (2003). História das Doutrinas Cooperativistas. Brasília: Confebrás.

MUCIÑO, M. E. I. (2008). La responsabilidade de las universidades públicas em México ante los

retos del sistema neoliberal. In: SOLER, Henrique Gadea. Boletín de la Asociación Internacional de Derecho Cooperativo (BAIDC), $n^{\circ} 42$ - universidad y cooperativismo. Bilbao: Deusto Publicaciones.

MUSA, O. R. (2017). La constitucionalización de la cooperativa: uma propuesta para su redimensionamiento en Cuba. Brasília, DF: Vincere Associados.

NAMORADO, Rui. (2000). Introdução ao Direito Cooperativo. Coimbra: Almedina. 

. Cooperatividade e Direito Cooperativo - estudos e pareceres. Coimbra: Almedina.

OLIVEIRA, A. F. de. (2014). Política consumerista, política antitruste e as cooperativas no Brasil. In: Congreso Continental de Derecho Cooperativo. CRACOGNA, D. (coord.), Ciudad Autónoma de Buenos Aires: Intercoop.

PERIUS, V. F. (2001). Cooperativismo e a lei. São Leopoldo: Editora Unisinos.

POPPER, K. R. (2013). A lógica da pesquisa científica. São Paulo: Cultrix.

PUENTE, A. S. (1954). Derecho Cooperativo. México: Editorial Cooperativo.

ROSE, M. T. de. (2008). Fidelidade societária. In: Cooperativas na ordem econômica constitucional: cooperativas, concorrência e consumidor: tomo II. KRUEGR, G. (coord). Belo Horizonte: Mandamentos.

SALOMÃO FILHO, C. (2012). Regulação, desenvolvimento e meio ambiente. In: SALOMÃO FILHO, C. (org). Regulação e desenvolvimento. São Paulo: Malheiros. . (2013). Direito Concorrencial. São Paulo, Malheiros.

SARLET, I. W. (2012). Liberdade de associação cooperativa, direitos e garantias fundamentais e relações privadas na perspectiva do Supremo Tribunal Brasileiro. In: MEIRA, Deolinda (coord). A jurisprudência cooperativa comentada - obra de comentários a acórdãos da jurisprudência portuguesa, brasileira e espanhola. Lisboa: INCM.

TELLECHEA, R. (2016). Autonomia privada no Direito Societário. São Paulo: Quartier Latin.

WARBASSE, J. P. (1975). Democracia cooperativa. Buenos Aires: Arengreen.

WEBER, M. (2000). Economia e sociedade. Vol. 1, Brasília: Editora UNB. 